\title{
Efektivitas Pemberian Biocurpain untuk Memperbaiki Status Fungsional pada Pasien Osteoarthritis
}

Rizaldy Taslim Pinzon ${ }^{1}$, Eric $^{2}$

${ }^{1}$ Departemen Neurologi, Fakultas Kedokteran Universitas Kristen Duta Wacana, Yogyakarta, Indonesia

${ }^{2}$ Fakultas Farmasi, Universitas Sanata Dharma, Yogyakarta, Indonesia

*Corresponding author: drpinzon17@gmail.com

Submitted: 23 Maret 2020

Accepted: 11 Mei 2020

Published: 25 Juni 2020

\begin{abstract}
Background: Osteoarthritis $(O A)$ is a progressive arthritis that decreases quality of life. This disease can not be cured and is limited and can only reduce pain experienced by patients. The drug that is often used is nonsteroidal anti-inflammatory drugs (NSAIDs), these medicines can not be separated from side effects if used in the long term. An effective and safe drug is needed to improve functional status in osteoarthritis paitents. Objective: To compared the effectiveness of biocurpain which has a marketing authorization number TR172599281 with NSAIDs to improves functional Status in the treatment of OA patients. Methods: A Randomized Control Trial (RCT) involving OA patients. The treatment used were Biocurpain (Curcuma longa $350 \mathrm{mg}$ and Boswellia serrata $150 \mathrm{mg}$ ) and NSAIDs (Ibuprofen $400 \mathrm{mg}$ ). Subjects were randomized into 2 groups (Group 1 received Biocurpain and group 2 recieved NSAIDs). Functional status measurement using Western Ontario and McMaster Universities Osteoarthritis Index (WOMAC). Results: There were 67 subjects that participated in this study, 5 subjects were lost to follow-up and 3 subjects could not continue the study due to side effects. 59 subjects completed the trial (group 1: 29 subjects and group 2: 30 subjects). There were no significant differences between groups in improving functional status ( $p: 0.771$ ), the use of rescue medication ( $p: 0.370)$, the incidence of adverse events at visit II (p: 0.215) and visit III (p: 0.537) on OA subjects. Group 2 showed more subjects experiencing side effects. Conclusion: Biocurpain as effective as NSAIDs to improve functional status in OA patients.
\end{abstract}

Keywords: osteoarthritis, Curcuma longa, Boswellia serrata, NSAIDs, WOMAC

\begin{abstract}
Abstrak
Pendahuluan: Osteoarthritis (OA) merupakan penyakit radang sendi progresif yang menurunkan kualitas hidup. Penyakit ini tidak dapat disembuhkan dan terbatas hanya mengurangi nyeri yang dialami oleh pasien. Obat yang sering digunakan adalah non-steroidal anti-inflammatory drugs (NSAIDs), namun penggunaan obat tersebut tidak terlepas dari efek samping jika digunakan dalam jangka panjang. Maka diperlukan obat yang efektif dan aman untuk memperbaiki status fungsional pada pasien osteoarthritis. Tujuan: membandingkan efektifitas dari pemberian Biocurpain yang memiliki Nomor Izin Edar (NIE) TR172599281 dengan NSAIDs untuk memperbaiki status fungsional pada terapi pasien OA. Metode: Penelitian ini menggunakan metode Randomized Control Trial (RCT) yang melibatkan pasien OA. Perlakuan yang diberikan berupa Biocurpain (Curcuma longa $300 \mathrm{mg}$ dan Boswellia serrata $150 \mathrm{mg}$ ) dan NSAIDs (ibuprofen $400 \mathrm{mg}$ ). Subjek diacak menjadi 2 kelompok (kelompok 1 memperoleh Biocurpain dan kelompok 2 memperoleh NSAIDs). Pengukuran status fungsional menggunakan Western Ontario and McMaster Universities Osteoarthritis Index (WOMAC). Hasil: Terdapat 67 subjek yang mengikuti penelitian ini, 5 subjek lost to follow up dan 3 subjek tidak dapat melanjutkan penelitian karena efek samping yang dirasakan. Sebanyak 59 subjek mengikuti penelitian hingga selesai (kelompok 1 berisi 29 subjek dan kelompok 2 berisi 30 subjek). Tidak ada perbedaan yang signifikan antar kelompok dalam memperbaiki status fungsional (p: 0,771), penggunaan rescue medication (p: 0,370), kejadian efek samping pada visit II $(0,215)$ dan visit III $(0,537)$ pada subjek OA. Kelompok 2 menunjukkan lebih banyak subjek yang
\end{abstract}


mengalami efek samping. Kesimpulan: Biocurpain memiliki efektivitas yang setara dengan NSAIDs dalam memperbaiki status fungsional pada pasien OA.

Kata kunci: osteoarthritis, Curcuma longa, Boswellia serrata, NSAIDs, WOMAC

\section{PENDAHULUAN}

Osteoarthritis (OA) adalah penyakit sendi degeneratif yang berhubungan dengan peradangan (Rahimnia dkk., 2014). OA dianggap penyakit radang sendi yang paling umum, merupakan radang sendi progresif yang lambat, membatasi pergerakan sendi dan mengurangi kualitas hidup secara signifikan (Ashfold \& Williard, 2014). Prevalensi OA pada negara Asia berkisar 36,1 hingga 46,8\% (Kuptniratsaikul dkk., 2014). Prevalensi masalah sendi di Indonesia sebesar 7,3\% dan di Yogyakarta sebesar 5,9\% (Kemenkes RI, 2018).

OA merupakan penyakit yang tidak dapat disembuhkan pengobatan konvensional terbatas pada penggunaan non-steroidal anti-inflammatory drugs (NSAIDs), suntikan kortikosteroid, dan analgesik. Terapi dengan NSAIDs dan analgesik seperti acetaminophen dapat menyebabkan efek samping, terutama jika digunakan dalam jangka panjang (Akuri dkk., 2017). Reaksi efek samping yang muncul seperti gastrointestinal (GI), dispepsia, ulserasi, pendarahan saluran cerna atas, perforasi lambung atau duodenum (Kuptniratsaikul dkk., 2014). Setelah mempertimbangkan potensi efek samping NSAIDs dan durasi perawatan yang panjang, akan lebih baik jika menggunakan obat yang lebih aman dan memiliki profil kesehatan yang baik (Pinzon \& Sanyasi, 2018).

Obat-obatan tradisional yang menggunakan senyawa tanaman menawarkan alternatif yang lebih aman untuk mengelola berbagai penyakit kronis. Salah satu formulasi yang telah dievaluasi adalah kombinasi Curcuma longa dan Boswellia serrata. Serangkaian penelitian telah menunjukkan bahwa ekstrak Curcuma longa yang mengandung curcumin merupakan agen anti inflamasi dan antioksidan dengan keamanan yang dapat diterima dengan baik. Ekstrak Boswellia serrata juga terbukti aman dan efektif dalam meredakan nyeri pada pasien OA (Karlapudi dkk., 2018). Curcumin memiliki kemampuan untuk menekan peradangan akut dan kronis. Penelitian in vitro tentang curcumin menunjukkan aksi anti inflamasi pada sel-sel pembuluh darah manusia. Aktivitas anti inflamasi dari curcumin merupakan hasil gabungan dari beberapa mekanisme. Curcumin memodulasi respon inflamasi dengan menurunkan aktivitas COX-2, menghambat produksi sitokin inflamasi dan menekan aktivasi NF-kB (Ross, 2016). Aktivitas Boswellia serrata muncul dari asam boswellic (AKBA), AKBA adalah penghambat jalur lipoksigenase dari metabolisme arakidonat dan memiliki sifat anti inflamasi dan anti kanker yang signifikan (Kizhakkedath, 2013).

Tujuan dari penelitian ini adalah untuk mengetahui apakah Biocurpain $500 \mathrm{mg}$ dengan Nomor Izin Edar (NIE) TR172599281 yang memiliki kandungan Curcuma longa $350 \mathrm{mg}$ dan Boswellia serrata $150 \mathrm{mg}$ memiliki efektivitas yang setara dengan NSAIDs dalam memperbaiki status fungsional di Rumah Sakit Bethesda Yogyakarta dan Rumah Sakit Panti Rapih Yogyakarta menggunakan lembar Western Ontario and Mcmaster Universities Arthritis Index (WOMAC) untuk mengukur nyeri, kekakuan, dan gangguan fungsional

\section{BAHAN DAN METODE \\ Bahan}

Obat yang digunakan adalah Biocurpain Force 500 $\mathrm{mg}$ dengan kandungan Curcuma longa $350 \mathrm{mg}$ dan Boswellia serrata $150 \mathrm{mg}$, NSAIDs (ibuprofen $400 \mathrm{mg}$ ) dan parasetamol (500 mg) sebagai rescue medication.

\section{Alat}

Menggunakan Case Report Form (CRF) yang berisi data diri pasien, kriteria inklusi dan eksklusi, lembar WOMAC, rescue medication, dan efek samping

\section{Rancangan penelitian}

Penelitian ini merupakan penelitian Randomized Control Trial. Subjek dibagi menjadi 2 kelompok secara acak. Terapi yang digunakan dalam penelitian ini adalah Biocurpain (350 mg Curcuma longa dan 150 $\mathrm{mg}$ Boswellia serrata) dan NSAIDs (400 mg ibuprofen atau $50 \mathrm{mg}$ natrium diklofenak). Setiap obat diminum 2 kali sehari selama 4 minggu. Sebanyak 20 tablet parasetamol $500 \mathrm{mg}$ diberikan kepada setiap subjek sebagai rescue medication, pasien mengonsumsi parasetamol 3 kali sehari jika merasakan nyeri setelah obat perlakuan tidak mengurangi nyeri yang dirasakan. Randomisasi dilakukan dengan bantuan kalkulator OpenEpi. 


\section{Subjek penelitian}

Ukuran sampel minimal yang diperlukan dalam penelitian ini dihitung dengan bantuan kalkulator ukuran sampel dari halaman web https://www.openepi.com/SampleSize/SSMean.htm menggunakan data rata-rata dan standar deviasi skor WOMAC merujuk dari penelitian yang telah dilakukan sebelumnya. Pada penelitian (Srivastava dkk., 2016), didapatkan rata-rata skor WOMAC pada kelompok kombinasi Curcuma longa dan Boswellia serrata sebesar 4,51 dan pada NSAIDs sebesar 12,05. Nilai standar deviasi berturut-turut sebesar 0,26 (kombinasi Curcuma longa dan Boswellia serrata) dan 0,21 NSAIDs. Data tersebut kemudian dimasukan sebagai input data pada kalkulator penghitung ukuran sampel. Dari hasil perhitungan kalkulator, persyaratan sampel minimum yang diperlukan dalam penelitian ini adalah sebesar 44 subjek untuk taraf kepercayaan 95\%.

Teknik pengumpulan sampel yang digunakan pada penelitian ini adalah nonprobability sampling dengan consecutive sampling, yaitu dengan cara mengambil semua subjek yang tersedia yang sesuai dengan kriteria inklusi dan eksklusi yang sudah ditetapkan (Sharma, 2014). Subjek penelitian ini adalah pasien OA di Rumah Sakit Bethesda Yogyakarta dan Rumah Sakit Panti Rapih Yogyakarta dengan memperhatikan beberapa kriteria inklusi dan eksklusi. Kriteria inklusi meliputi pasien pria atau wanita, usia $>18$ tahun (dewasa), memiliki tingkat Kellgren-Lawrence (KL) 23 (berdasarkan radiologi lutut). Kriteria eksklusi meliputi pasien yang menolak untuk mengikuti penelitian, pasien yang hipersensitif dengan Curcuma longa, Boswellia serrata dan NSAIDs, mengikuti percobaan klinik lain, tidak dapat memberikan persetujuan dan mengisi kuesioner, sedang hamil atau rencana untuk hamil selama penelitian berlangsung, dan mendapat terapi nyeri lain dalam 24 jam.

Tabel 1. Tabel western ontario and mcmaster universities osteoarthritis index (WOMAC) Skala: $0=$ tidak ada, $1=$ sedikit, $2=$ sedang, $3=$ berat, $4=$ sangat berat

\begin{tabular}{|c|c|c|c|c|c|c|c|}
\hline \multirow[t]{5}{*}{ Nyeri } & 1. & Berjalan & 0 & 1 & 2 & 3 & 4 \\
\hline & 2. & Menaiki tangga & 0 & 1 & 2 & 3 & 4 \\
\hline & 3. & Tidur di malam hari & 0 & 1 & 2 & 3 & 4 \\
\hline & 4. & Istirahat & 0 & 1 & 2 & 3 & 4 \\
\hline & 5. & Saat menumpu dan menapak & 0 & 1 & 2 & 3 & 4 \\
\hline \multirow[t]{2}{*}{ Kekakuan } & 1. & Kekakuan pagi hari & 0 & 1 & 2 & 3 & 4 \\
\hline & 2. & Kekakuan malam hari & 0 & 1 & 2 & 3 & 4 \\
\hline \multirow[t]{17}{*}{ Fungsi fisik } & 1. & Kesulitan naik tangga & 0 & 1 & 2 & 3 & 4 \\
\hline & 2. & Kesulitan turun tangga & 0 & 1 & 2 & 3 & 4 \\
\hline & 3. & Kesulitan dari posisi duduk ke berdiri & 0 & 1 & 2 & 3 & 4 \\
\hline & 4. & Kesulitan berdiri & 0 & 1 & 2 & 3 & 4 \\
\hline & 5. & Kesulitan duduk di lantai & 0 & 1 & 2 & 3 & 4 \\
\hline & 6. & Kesulitan berjalan di permukaan datar & 0 & 1 & 2 & 3 & 4 \\
\hline & 7. & Kesulitan naik/turun tangga & 0 & 1 & 2 & 3 & 4 \\
\hline & 8. & Kesulitan berbelanja & 0 & 1 & 2 & 3 & 4 \\
\hline & 9. & Kesulitan memakai kaos kaki & 0 & 1 & 2 & 3 & 4 \\
\hline & 10. & Kesulitan melepas kaos kaki & 0 & 1 & 2 & 3 & 4 \\
\hline & 11. & Kesulitan bangun dari tempat tidur & 0 & 1 & 2 & 3 & 4 \\
\hline & 12. & Kesulitan berbaring ditempat tidur & 0 & 1 & 2 & 3 & 4 \\
\hline & 13. & Kesulitan duduk & 0 & 1 & 2 & 3 & 4 \\
\hline & 14. & Kesulitan aktivitas mandi & 0 & 1 & 2 & 3 & 4 \\
\hline & 15. & Kesulitan melakukan BAK/BAB & 0 & 1 & 2 & 3 & 4 \\
\hline & 16. & Kesulitan melakukan tugas berat & 0 & 1 & 2 & 3 & 4 \\
\hline & 17. & Kesulitan melakukan tugas ringan & 0 & 1 & 2 & 3 & 4 \\
\hline
\end{tabular}

\section{Variabel}

Profil demografis meliputi jenis kelamin, usia, pekerjaan, status nikah, latar belakang pendidikan, komorbiditas dan derajat osteoarthritis. Derajat osteoarthritis diukur menggunakan skala KellgrennLawrence (KL). WOMAC merupakan instrumen yang mudah diberikan guna untuk mengevaluasi hasil P-ISSN: 2406-9388 E-ISSN: 2580-8303 intervensi OA baik konservatif maupun pembedahan, WOMAC terdiri dari 24 item, 5 item untuk mengukur nyeri, 2 item untuk mengukur kekakuan, dan 17 item untuk mengukur fungsi fisik (Tabel 1). Subjek akan diminta untuk menjawab pertanyaan seputar rasa sakit, kekakuan atau gangguan fungsional yang dialami dalam 4 jam sebelumnya (Ackerman, 2009). Setiap 
pertanyaan memiliki 5 subskala $(0=$ tidak ada, $1=$ sedikit, 2 = sedang, 3 = berat, 4 = sangat berat) (Ebrahimzadeh dkk., 2014). Rentan skor untuk nyeri, kekakuan dan fungsi fisik berturut-turut adalah $0-20$, 0 - 8, dan 0 - 68 dengan total keseluruhan skor sebesar 96, semakin tinggi skor WOMAC menunjukkan semakin parah gejala OA yang dirasakan. Penelitian ini telah disetujui oleh komisi etik Fakultas Kedokteran Universitas Duta Wacana, Yogyakarta, Indonesia. Nomor kelaikan etik penelitian adalah 867/C.16/FK/2018. Gambar 1 menunjukkan alur penelitian dan jumlah subjek yang mengikuti penelitian hingga selesai.

\section{Analisis data}

Analisis data menggunakan prinsip intention to treat, semua pasien yang telah diacak akan dianalisis, baik selama perlakuan mengalami gangguan, dihentikan sebelum waktu penelitian selesai atau tidak terjadi sama sekali (Kabisch dkk., 2011). Setelah melewati test normalitas menggunakan Shapiro-Wilk, analisis variabel menggunakan $t$ test atau wilcoxon. Tingkat signifikansi ditetapkan pada $\mathrm{p}<0,05$.

\section{HASIL DAN PEMBAHASAN}

Terdapat 67 subjek pada awal penelitian yang didominasi oleh perempuan $(76,1 \%)$ dengan rerata usia 64 tahun dan tingkat KL II $(56,7 \%)$. Gambar 1 menunjukkan alur penelitian terkait terkait dengan subjek. Terdapat 3 pasien yang dieksklusi dari penelitian karena efek samping (1 dari kelompok I dan 2 dari kelompok II) yang dirasakan dan 5 pasien lost to follow up (4 dari kelompok I dan 1 dari kelompok II).
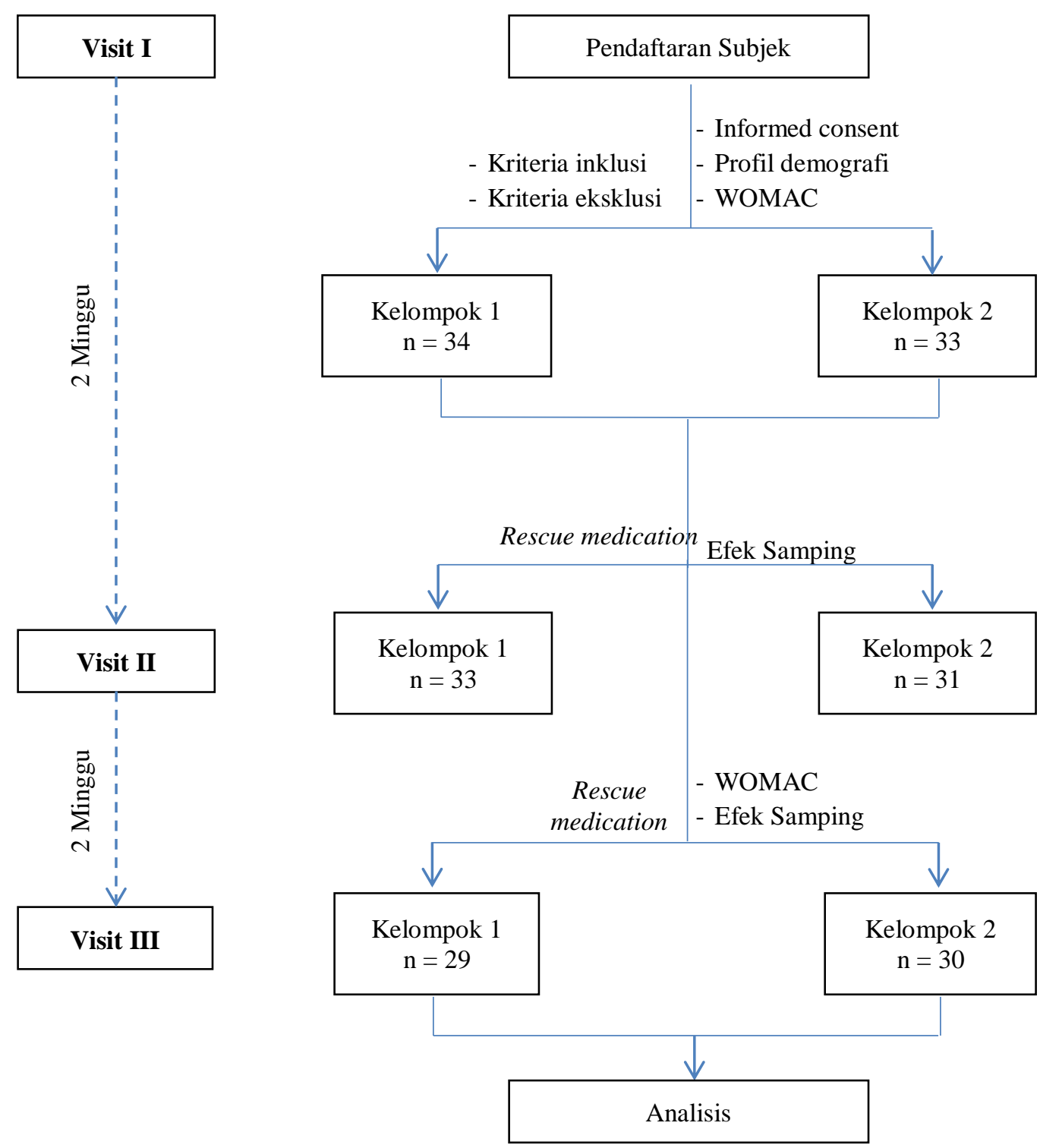

Gambar 1. Alur penelitian 
Pada Tabel 2 menunjukkan Karakteristik dasar subjek, terdapat 67 subjek pada awal penelitian yang didominasi oleh perempuan $(76,1 \%)$ dengan rata-rata usia 64 tahun, menikah $(76,1 \%)$, tingkat KellgrenLawrence (KL) II (56,7\%), dan hipertensi (52,2\%). Hasil diatas menunjukkan usia, jenis kelamin status nikah, pekerjaan, tingkat KL dam komorbiditas lain tidak memiliki hubungan dengan OA. Usia merupakan faktor utama seseorang terkena OA. Ada berbagai faktor yang menunjukkan hubungan antara usia dengan terjadinya OA seperti kerusakan oksidatif, penipisan tulang rawan, melemahnya otot, dan penurunan rangsangan (Palazzo dkk., 2016). Bertambahnya usia menyebabkan ketegangan dari tulang rawan menurun sehingga mengakibatkan akumulasi dari glycation yang menyebabkan kerusakan dari tulang rawan dan kemampuan tubuh untuk memperbaiki kartilago berkurang, seiring bertambahnya usia (Ahmad dkk., 2018). Bertambahnya usia juga menyebabkan prevalensi wanita lebih besar kemungkinan untuk terkena OA dikarenakan faktor hormonal (berkurangnya volume tulang rawan, kehilangan tulang atau berkurangnya massa otot) dan semakin faktor hormonal ini meningkat setelah menopause (Palazzo dkk., 2016). Penurunan kadar estrogen yang signifikan setelah menopause mengakibatkan peningkatan insiden OA pada wanita diatas 50 tahun, pada kondrosit terdapat reseptor estrogen yang menunjukkan bahwa sel-sel ini juga dipengaruhi oleh estrogen (Ahmad dkk., 2018).

Tabel 2. Karakteristik dasar

\begin{tabular}{|c|c|c|c|c|c|}
\hline \multicolumn{2}{|c|}{ Karakteristik } & $\begin{array}{l}\text { Curcuma longa dan } \\
\text { Boswellia serrata } \\
\text { n }(\%)\end{array}$ & $\begin{array}{l}\text { NSAIDs } \\
\mathrm{n}(\%)\end{array}$ & $\begin{array}{l}\text { Total } \\
\mathrm{n}(\%)\end{array}$ & $\mathrm{p}$ \\
\hline & Usia & $64 \pm 9,3$ & $64 \pm 9,5$ & $64 \pm 9,3$ & $0,988^{\mathrm{a}}$ \\
\hline \multirow{2}{*}{ Jenis Kelamin } & Laki-laki & $9(26,5)$ & $7(21,2)$ & $16(23,9)$ & \multirow{2}{*}{$0,614^{b}$} \\
\hline & Perempuan & $25(73,5)$ & $26(78,8)$ & $51(76,1)$ & \\
\hline \multirow{3}{*}{ Status } & Menikah & $29(85,3)$ & $22(66,7)$ & $51(76,1)$ & \multirow{3}{*}{$0,080^{\mathrm{b}}$} \\
\hline & Cerai & $3(8,8)$ & $10(30,3)$ & $13(19,4)$ & \\
\hline & Belum menikah & $2(5,9)$ & $1(3,0)$ & $3(4,5)$ & \\
\hline \multirow{6}{*}{ Pekerjaan } & Pegawai negeri sipil & $2(5,9)$ & $0(0)$ & $2(3)$ & \multirow{6}{*}{$0,254^{b}$} \\
\hline & Pengusaha & $4(11,8)$ & $3(9,1)$ & $7(10,4)$ & \\
\hline & Pegawai swasta & $3(8,8)$ & $1(3,0)$ & $4(6)$ & \\
\hline & Pensiun & $7(20,6)$ & $15(45,5)$ & $22(32)$ & \\
\hline & Penggangguran & $1(2,9)$ & $1(3,0)$ & $2(3)$ & \\
\hline & Lainnya & $17(50)$ & $13(39,4)$ & $30(44,8)$ & \\
\hline \multirow{2}{*}{ Tingkat KL } & Tingkat II & $18(52,9)$ & $20(60,6)$ & $38(56,7)$ & \multirow{2}{*}{$0,527^{b}$} \\
\hline & Tingkat III & $16(47,1)$ & $13(39,4)$ & $29(43,3)$ & \\
\hline \multirow{5}{*}{$\begin{array}{l}\text { Komorbiditas } \\
\text { Lain }\end{array}$} & Hipertensi & $17(50)$ & $18(54,5)$ & $35(52,2)$ & $0,710^{\mathrm{b}}$ \\
\hline & Diabetes melitus & $3(8,8)$ & $6(18,2)$ & $9(13,4)$ & $0,261^{\mathrm{b}}$ \\
\hline & Kardiovaskular & $5(14,7)$ & $6(18,2)$ & $11(16,4)$ & $0,701^{\mathrm{b}}$ \\
\hline & Gastrointestinal & $10(29,4)$ & $5(15,2)$ & $15(22,4)$ & $0,162^{\mathrm{b}}$ \\
\hline & Lainnya & $7(20,6)$ & $6(18,2)$ & $13(19,4)$ & $0,803^{\mathrm{b}}$ \\
\hline
\end{tabular}

${ }^{\mathrm{a}} \mathrm{T}$ Test tidak berpasangan

${ }^{\mathrm{b}}$ Tes chi-square

p menggunakan taraf kepercayaan $95 \%$

(\%) persentase jumlah pada masing-masing karakteristik

Tabel 3 menunjukkan efektivitas dari masingmasing kelompok yang dilihat dari rata-rata skor WOMAC pada visit I dan visit III. Hasil dari penelitian ini menunjukkan penurunan skor WOMAC yang signifikan pada kelompok I dan kelompok II setelah pemberian 4 minggu, namun tidak ada perbedaan yang signifikan antar kelompok. Hasil dari penelitian ini serupa dengan penelitian (Kizhakkedath, 2013) dimana baik kelompok kombinasi Curcuma longa dan Boswellia serrata serta kelompok NSAIDs efektif dalam memperbaiki status fungsional. Hal ini P-ISSN: 2406-9388

E-ISSN: 2580-8303 dikarenakan kandungan Curcumin pada C. longa dapat menghambat efek substan yang berhubungan dengan jalur inflamasi seperti cyclooxygenase (COX) (Kuptniratsaikul dkk., 2014). Curcumin memodulasi respon inflamasi dengan menurunkan aktivitas cyclooxygenase (COX-2), menghambat produksi sitokin inflamasi seperti interferon, interleukin dan faktor nekrosis tumor (Ross, 2016). Sedangkan aktivitas dari Boswellia serrata muncul dari adanya kandungan asam boswellic, dimana asam 3-O-acetyl11-keto-boswellic (AKBA) adalah yang paling aktif. 
AKBA menghambat jalur lipoksigenase dari metabolisme arakidonat dan memiliki efek antiinflamasi dan antikanker yang signifikan. Sehingga,
Boswellia serrata menghambat penurunan kadar glikosaminoglikan yang berfungsi untuk memperbaiki tulang rawan (Kizhakkedath, 2013).

Tabel 3. Perbandingan skor WOMAC sebelum dan sesudah pemberian terapi pada kedua kelompok

\begin{tabular}{llcc}
\hline Kelompok & WOMAC visit I & WOMAC visit II & $\mathrm{p}^{\mathrm{a}}$ \\
\hline Biocurpain & $35,3 \pm 17,5$ & $23,5 \pm 21,5$ & $0,001^{*}$ \\
NSAIDs & $35,7 \pm 20,4$ & $25,3 \pm 22,5$ & $0,005^{*}$ \\
\hline * signifikan & & & \\
a $t$ t test berpasangan & & &
\end{tabular}

Tabel 4 menunjukkan delta $(\Delta)$ WOMAC yang diperoleh dari pengurangan skor WOMAC pada Visit I dan visit III. Rata-rata $\triangle$ WOMAC tertinggi dapat dilihat pada kelompok Biocurpain. Hasil tersebut menunjukkan tidak terdapat perbedaan secara statistik skor $\triangle$ WOMAC antar kelompok. Hasil dari penelitian ini juga sesuai dengan penelitian (Kizhakkedath, 2013) dimana tidak terjadi perbedaan penurunan skor
WOMAC yang signifikan antar kelompok. Penelitian (Kuptniratsaikul dkk., 2014) juga menunjukkan bahwa Curcuma longa memiliki efektivitas yang sama dengan ibuprofen dalam terapi pasien OA. Penelitian yang dilakukan oleh (Ross, 2016) juga menunjukkan bahwa ekstrak curcumin memiliki efektivitas yang sama dengan ibuprofen untuk mengobati nyeri pada pasien OA.

Tabel 4. Perbandingan selisih $(\Delta)$ WOMAC pada visit iii dan visit i pada kedua kelompok

\begin{tabular}{ccc}
\hline Kelompok & Rerata $\Delta$ WOMAC & $\mathrm{p}^{\mathrm{a}}$ \\
\hline Biocurpain & $11,7 \pm 18,1$ & 0,771 \\
NSAIDs & $10,4 \pm 19,9$ & \\
t test tidak berpasangan & &
\end{tabular}

Tabel 5 menujukkan rata-rata sisa rescue medcation yang telah digunakan oleh pasien, penggunaan rescue medication tertinggi terjadi pada kelompok NSAIDs, tidak terdapat perbedaan secara statistik penggunaan rescue medication antar kelompok. Rescue medication sering digunakan untuk mengelola nyeri yang dialami oleh pasien yang tidak terkontrol setelah menggunakan obat perlakuan. Mengukur penggunaan rescue medication memberikan informasi penting untuk mengetahui kekokohan efek analgesik, obat analgesik yang efektif harus mengurangi kebutuhan penggunaan rescue medication (Kivitz dkk., 2019). Pada penelitian ini, kelompok I menunjukkan konsumsi rescue medication yang lebih sedikit jika dibandingkan dengan NSAIDs. Hasil dari penelitian ini sesuai dengan (Kizhakkedath, 2013) yang menunjukkan bahwa tidak ada perbedaan secara statistik pemberian rescue medication pada kedua kelompok, dan penelitian (Onakpoya dkk., 2017) juga menunjukkan bahwa pemberian kombinasi Curcuma longa dan Boswellia serrata dapat menurunkan penggunaan rescue medication.

Tabel 5. Perbandingan Penggunaan Parasetamol Sebagai Rescue Medication

\begin{tabular}{ccc}
\hline Kelompok & Rerata sisa rescue medication & $\mathrm{p}^{\mathrm{a}}$ \\
\hline Biocurpain (n: 29) & $7 \pm 6,8$ & 0,370 \\
NSAIDs (30) & $5 \pm 5,8$ & \\
\hline${ }^{\mathrm{a}}$ tes Man-whitney & &
\end{tabular}

Tabel 6 menunjukkan kejadian efek samping yang dirasakan oleh masing-masing kelompok. Nyeri perut merupakan gejala efek yang paling sering dirasakan oleh kelompok NSAIDs $(\mathrm{n}=7)$. Tiga subjek tidak dapat mengikuti penelitian dikarenakan efek samping yang dirasakan (satu dari kelompok Biocurpain dan satu dari kelompok NSAIDs), tidak terdapat efek samping yang serius pada penelitian ini. Terdapat satu efek samping yang berhubungan dengan Biocurpain yaitu pusing dan lima efek samping yang berhubungan dengan NSAIDs yaitu nyeri pada bagian perut. Tabel 6 menunjukkan tidak terdapat perbedaan secara statistik efek samping yang timbul pada antar kelompok pada visit II (p: 0,215) dan visit III (p: 0,537). Nyeri perut lebih sering dialami oleh kelompok NSAIDs dikarenakan NSAIDs menghambat sintesa prostaglandin melalui inhibisi cyclooxygenase (enzim COX-1 dan COX-2). COX-1 adalah enzim yang terlibat dalam produksi prostaglandin gastroprotektif dan berada secara terus-menerus di mukosa gastrik. 
Sedangkan COX-2 tidak selalu ada dalam jaringan, namun akan muncul apabila dirangsang oleh mediator inflamasi. Penghambatan COX-1 akan menyebabkan peningkatan risiko perdarahan karena ada hambatan agregasi platelet. Penghambatan COX-2 akan berefek antiinflamasi dan analgesik (DiPiro dkk., 2011). Kelompok NSAIDs juga menyebabkan lebih banyak pasien yang dikeluarkan dari penelitian karena efek samping yang timbul. Hasil ini sesuai dengan penelitian sebelumnya, dimana jumlah efek samping seperti nyeri pada bagian perut atau ketidaknyamanan secara signifikan lebih tinggi pada kelompok NSAIDs jika dibandingkan dengan kelompok Curcuma longa (Kuptniratsaikul dkk., 2014). Pada penelitian (Shep dkk., 2019) juga menunjukkan bahwa subjek yang menerima curcumin lebih sedikit mengalami efek samping terkait GI jika dibandingkan dengan subjek yang menerima NSAIDs. Hal tersebut dapat disebabkan karena efek protektif curcumin terhadap mukosa lambung. Curcumin menghambat sekresi interleukin 6 (yang mengaktifkan neutrofil, limfosit dan monosit yang berperan pada kerusakan jaringan pada lambung).

Tabel 6. Perbandingan Kejadian Efek Samping pada Kedua Kelompok

\begin{tabular}{|c|c|c|c|c|}
\hline Kelompok & Visit II & $\mathrm{p}^{\mathrm{a}}$ & Visit III & $\mathrm{p}^{\mathrm{a}}$ \\
\hline $\begin{array}{l}\text { Biocurpain (n: 4) } \\
\text { NSAIDs (n: 7) }\end{array}$ & $\begin{array}{l}2 \text { (pusing dan urtikaria) } \\
5 \text { (nyeri pada baigan perut) }\end{array}$ & 0,215 & $\begin{array}{c}2 \text { (mual, dan kehilangan nafsu makan, pusing) } \\
2 \text { (nyeri pada bagian perut) }\end{array}$ & 0,537 \\
\hline
\end{tabular}

Kelebihan dari penelitian ini adalah dilakukan randomisasi, perancu terbagi sama antar kedua kelompok uji. Penelitian ini masih memiliki keterbatasan dimana penelitian ini adalah penelitian open label sehingga tidak dilakukan pembutaan (blinding) saat dilakukan randomisasi, jika tidak dilakukan blinding akan memungkinkan terjadinya bias informasi.

\section{KESIMPULAN}

Pemberian Biocurpain memiliki efektivitas yang setara dengan NSAIDs dalam memperbaiki status fungsional pada pasien osteoarthritis.

\section{DAFTAR PUSTAKA}

Ackerman, I. (2009). Western Ontario and Mcmaster Universities Osteoarthritis Index (WOMAC). Australian Journal of Physiotherapy; 55; 213.

Ahmad, I. W., Rahmawati, L. D. \& Wardhana, T. H. (2018). Demographic Profile, Clinical and Analysis of Osteoarthritis Patients in Surabaya. Biomolecular and Health Science Journal; 1; 34-39.

Akuri, M. C., Barbalho, S. M., Val, R. M. \& Guiguer, E. L. (2017). Reflections About Osteoarthritis and Curcuma longa. Pharmacognosy Reviews; $11 ; 8-12$.

Ashfold, S. \& Williard, J. (2014). Osteoarthritis: A Review. Walter Kluwer Health; 39; 1-8.

Dipiro, J. T., Talbert, R. L., Yee, G. C., Matzke, G. R., Wells, B. G. \& Posey, M. (2011) Pharmacotherapy: A Pathophysiologic Approach (8th edition). New York: Mc Graw
Hill.

Ebrahimzadeh, M. H., Makhmalbaf, H., Birjandinejad, A., Keshtan, F. G., Hoseini, H. A. \& Mazloumi, S. M. (2014). The Western Ontario and McMaster Universities Osteoarthritis Index (WOMAC) in Persian Speaking Patients with Knee Osteoarthritis. The Archives of Bone and Joint Surgery; 2; 57-62.

Kabisch, M., Ruckes, C., Seibert-grafe, M. \& Blettner, M. (2011). Randomized Controlled Trials; 108; 663-668.

Karlapudi, V., Prasad, M. A. V., Sengupta, K., Davis, B. A. \& Raychaudhuri, S. P. (2018). A PlaceboControlled Double-Blind Study Demonstrates the Clinical Efficacy of a Novel Herbal Formulation fo Relieving Joint Discomfort in Human Subjects with Osteoarthritis of Knee. Journal Of Medicine Food; 21; 1-10.

Kemenkes RI. (2018). Hasil Utama RISKESDAS 2018. Jakarta: Kementerian Kesehatan Badan Penelitian dan Pengembangan Kesehatan.

Kivitz, A. J., Conaghan, P. G., Cinar, A., Lufkin, J. \& Kelley, S. D. (2019). Rescue Analgesic Medication Use by Patients Treated with Triamcinolone Acetonide Extended-Release for Knee Osteoarthritis Pain: Pooled Analysis of Three Phase 2/3 Randomized Clinical Trials. Pain and Therapy; 8; 271-280.

Kizhakkedath, R. (2013). Clinical evaluation of a Formulation Containing Curcuma longa and Boswellia serrata Extracts in the Management of Knee Osteoarthritis. Molecular Medicine Reports; 8; 1542-1548. 
Ackerman, I. (2009). Western ontario and mcmaster universities osteoarthritis index (WOMAC). Australian Journal of Physiotherapy, 213.

Ahmad, I. W., Rahmawati, L. D., \& Wardhana, T. H. (2018). Demographic Profile, Clinical and Analysis of Osteoarthritis Patients in Surabaya. Biomolecular and Health Science Journal.

Akuri, M. C., Barbalho, S. M., Val, R. M., \& Guiguer, E. L. (2017). Reflections about Osteoarthritis and Curcuma longa. Pharmacognosy Reviews, 8-12.

Ashfold, S., \& Williard, J. (2014). Osteoarthritis: A Reviews. Walter Kluwer Health, 3-9.

Dipiro, J. T., Talbert, R. L., Yee, G. C., Matzke, G. R., Wells, B. G., \& Posey, M. (2011). Pharmacotherapy: A Patophysiologic Approach 8 Edition . New York: Mc Graw Hill.

Ebrahimzadeh, M. H., Makhmalbaf, H., Birjandinejad, A., Keshtan, F. G., Hoseini, H. A., \& Mazloumi, S. M. (2014). The Western Ontario and McMaster Universities Osteoarthritis Index (WOMAC) in Persian Speaking Patients with Knee Osteoarthritis. The archives of bone and joint surgery, 57-62.

Kabisch, M., Ruckes, C., Seibert-grafe, M., \& Blettner, M. (2011). Randomized Controlled Trials. Deutsches Aerzteblatt.

Karlapudi, V., Prasad Mungara, A. V., Sengupta, K., Davis, B. A., \& Raychaudhuri, S. P. (2018). A Placebo-Controlled Double-Blind Study Demonstrates the Clinical Efficacy of a Novel Herbal Formulation fo Relieving Joint Discomfort in Human Subjects with Osteoarthritis of Knee. Journal of Medicinal Food, 511-520.

Kelley, S. D., Cinar, A., \& Lufkin, J. (2019). Rescue Analgesic Medication Use by Patients Treated with Triamcinolone Acetonide ExtendedRelease for Knee Osteoarthritis Pain : Pooled Analysis of Three Phase 2 / 3 Randomized Clinical Trials. Pain and Therapy.

Kemeskes RI. (2018). Hasil Utama RISKESDAS 2018. Jakarta: Kementerian Kesehatan Badan Penelitian dan Pengembangan Kesehatan.

Kizhakkedath, R. (2013). Clinical Evaluation of a Formulation Containing Curcuma longa and Boswellia serrata Extracts in the Management of Knee Osteoarthritis. Molecular Medicine Reports; 8; 1542-1548.

Kuptniratsaikul, V., Dajpratham, P., Taechaarpornkul, W., Buntragulpoontawee, M.,
Lukkanapichonchut, P., Chootip, C., Saengsuwan, J., Tantayakon, K. \& Laongpech, S. (2014). Efficacy and Safety of Curcuma domestica Extracts Compared With Ibuprofen in Patients with Knee Osteoarthritis: A Multicenter Study. Clinical Interventions in Aging; 9; 451458.

Onakpoya, I. J., Spencer, E. A., Perera, R. \& Heneghan, C. J. (2017). Effectiveness of Curcuminoids in the Treatment of Knee Osteoarthritis: A Systematic Review and Meta-analysis of Randomized Clinical Trials. International Journal of Rheumatic Diseases; 20; 420-433.

Palazzo, C., Nguyen, C., Colau, M. M., Rannou, F. \& Poiraudeau, S. (2016). Risk Factors and Burden of Osteoarthritis. Annals of Physical and Rehabilitiation Medicine; 59; 134-138.

Pinzon, R. T. \& Sanyasi, R. D. L. R. (2018). Curcuma longa for Arthritis Pain: Systematic Review of Randomized Controlled Trial Study. Asian Journal of Pharmacy and Pharmacology; 4; 528-534.

Rahimnia, A. R., Panahi, Y., Alishiri, G., Sharafi, M. \& Sahebkar, A. (2014). Impact of Supplementation with Curcuminoids on Systemic Inflammation in Patients with Knee Osteoarthritis: Findings from a Randomized Double-blind Placebo-controlled trial. Drug Research; 65; 521-525.

Ross, S. M. (2016). Turmeric (Curcuma longa): Effects of Curcuma longa Extracts Compared with Ibuprofen for Reduction of Pain and Functional Improvement in Patients with Knee Osteoarthritis. Holistic Nursing Practice; 30; 183-186.

Sharma, S. (2014) Nursing Research and Statistic. India: Reed Elsecier India Privvate Limited.

Shep, D., Khanwelkar, C., Gade, P. \& Karad, S. (2019). Safety and Efficacy of Curcumin Versus Diclofenac in Knee Osteoarthritis: A Randomized Open-label Parallel-arm Study. Trials; 20; 1-11.

Srivastava, S., Saksena, A. K., Khattri, S., Kumar, S. \& Dagur, R. S. (2016). Curcuma longa Extract Reduces Inflammatory and Axidative Stress Biomarkers in Osteoarthritis of Knee: A Fourmonth, Double-blind, Randomized, Placebocontrolled Trial. Inflammopharmacology; 24; 377-388. 